\title{
Preliminary overview and evaluation of a stepped solar distiller with internal reflective walls and borosilicate vacuum tubes
}

\author{
Erich Saettone $^{\mathrm{a}, *}$, Yohan Valencia-Tovar ${ }^{\mathrm{b}}$, Alberto Gómez-de-la-Torre-Gastello ${ }^{\mathrm{b}}$ \\ a Institute of Scientific Research (IDIC), University of Lima, Peru \\ ${ }^{\mathrm{b}}$ Faculty of Industrial Engineering, University of Lima, Peru
}

\section{H I G H L I G H T S}

- Description of a novel solar stepped distiller with internal reflective walls and a set of borosilicate vacuum tubes.

- Global efficiency average of $71.5 \%$.

- Fresh water production varies from $5690 \mathrm{~cm}^{3} / \mathrm{m}^{2} /$ day on sunny days to $3648 \mathrm{~cm}^{3} / \mathrm{m}^{2} /$ day on cloudy days.

- Water production regardless of distiller's size and total solar energy varies slightly for different weather conditions.

- $V^{\prime \prime}{ }_{\text {exp }}$ characterizes the distiller's performance: $285.5 \mathrm{~cm}^{3} / \mathrm{m}^{2} / \mathrm{MJ} /$ day on sunny days and $288.8 \mathrm{~cm}^{3} / \mathrm{m}^{2} / \mathrm{MJ} /$ day on cloudy days.

- The use of the set of vacuum tubes in the stepped distiller enhanced its performance in $32.4 \%$.

\section{A R T I C L E I N F O}

\section{Article history:}

Received 27 August 2016

Received in revised form 21 February 2017

Accepted 12 March 2017

Available online $\mathrm{xxxx}$

\section{Keywords:}

Solar energy

Seawater desalination

Solar distiller

Stepped solar distiller

Borosilicate vacuum tube with heat pipe

\begin{abstract}
A B S T R A C T
The present study demonstrates that the current use of stepped solar distillers can be enhanced to increase seawater desalination. To this end, we designed a stepped solar still with internal reflective walls and attached a set of borosilicate vacuum tubes with heat pipes; these heat pipes, in turn, were attached to plates containing seawater inside the distiller. The average global efficiency was calculated in $71.5 \%$; the volume of distilled water per unit area (designated as $V_{\text {exp }}^{\prime}$ ) and the volume of distilled water per unit area of distiller and per unit daily solar energy $\left(V^{\prime \prime}{ }_{\text {exp }}\right)$ were also calculated. On a sunny day, with an incident solar energy of $19.93 \mathrm{MJ} / \mathrm{m}^{2}, V_{\mathrm{i}}^{\prime}$ was $5690 \mathrm{~cm}^{3} / \mathrm{m}^{2}$ and $V^{\prime \prime}$ exp was $285.5 \mathrm{~cm}^{3} / \mathrm{m}^{2} \mathrm{MJ}$; meanwhile, on a cloudy day, with $12.63 \mathrm{MJ} / \mathrm{m}^{2}$ of energy, $V_{\text {exp }}^{\prime}$ was $3648 \mathrm{~cm}^{3} / \mathrm{m}^{2}$ and $V^{\prime \prime}$ exp was $288.8 \mathrm{~cm}^{3} / \mathrm{m}^{2}$ MJ. Since $V^{\prime \prime}{ }_{\text {exp }}$ varies only slightly under different weather conditions, we propose that it should be used to compare the performance of stepped solar stills that do and do not contain vacuum tubes. Thus, it was proved that the still containing the vacuum tubes had a global efficiency and $V^{\prime \prime}{ }_{\exp }$ that were $32.4 \%$ greater than those without vacuum tubes.
\end{abstract}

(c) 2017 Elsevier B.V. All rights reserved.

\section{Introduction}

In Peru, approximately $30 \%$ of the children living in rural areas suffer from chronic malnutrition; this is caused not only by poor nutrition but also by unsafe water consumption [1]. Solar desalination is a potential solution for alleviating water scarcity in poor and rural areas close to the coastline because it is a simple and low-cost technology that requires very low maintenance. Although this technique goes back almost 100 years, its use has been sporadic and unsustainable. Nevertheless, research is still being conducted today on the methods and materials that allow for the efficiency and production of desalinated water to increase; unfortunately, the production processes often involve considerable loss

\footnotetext{
* Corresponding author.

E-mail address: esaetton@ulima.edu.pe (E. Saettone).
}

of heat to the environment. This makes solar stills relatively inefficient in terms of performance and results in the production of small amounts of water (between 1 and $8 \mathrm{~L}$ per square meter of the covered surface of the still). This variation is due to both the geometry of the still and the materials used for its construction. One type of distiller that has demonstrated a better level of performance is the stepped still [2]; however, more productive stills have been reported to exist [3].

Moustafa et al. [4] are pioneers in calculating the efficiency of a stepped still, and they have determined its value to be $24 \%-30 \%$. Similarly, Muslih et al. [5] showed, under the same weather conditions, that while a flat-plate still produces $1390 \mathrm{~cm}^{3} / \mathrm{m}^{2}$ of water per day, a stepped still produces $4340 \mathrm{~cm}^{3} / \mathrm{m}^{2}$ of water, which is almost three times greater.

Similarly, Abdullah [6] achieved a 30\% increase when producing desalinated water using a cascade still as compared with a flat-plate still 
(4350 against $3550 \mathrm{~cm}^{3} / \mathrm{m}^{2}$ per day). He explained that this variation results from the cascade still having a smaller air volume within its interior, which makes the heating process faster. This causes a greater transfer of heat and mass toward seawater. He reported an $85 \%$ increase in the production when comparing a flat-plate still and a stepped still with hot air flow onto the base of each plate (3400 against $6300 \mathrm{~cm}^{3} / \mathrm{m}^{2}$ per day); additionally, he claimed that a stepped still embedded with cooling of the glass cover produces $65 \%$ more water than a flat-plate still does. Finally, he describes a stepped distiller with hot air flow and simultaneous cooling of the glass cover, which produces $112 \%$ more desalinated water than a conventional flat-plate still.

Velmurugan et al. [7], meanwhile, used heat-absorbing materials such as sponges and stones on the plates of a stepped distiller, which allows an increase of $98 \%$ in the production of desalinated water compared with stepped stills without these materials. Similarly, Omara et al. [8] compared the amounts of desalinated water produced by a flatplate still, stepped still, and stepped still with internal reflective walls. They found that the stepped still produced 57\% more desalinated water than the flat-plate still, whereas the stepped still with the internal reflective walls produced $75 \%$ more water than the flat-plate still. Omara et al. [9] also reported that a stepped still with internal reflective walls and two external reflective walls could produce $125 \%$ more water than a flat-plate still and thereby distil $8100 \mathrm{~cm}^{3} / \mathrm{m}^{2}$ of water per day.

Another way to desalinate greater volumes of seawater is by collecting heat through borosilicate vacuum tubes with or without heat pipes; such a structure allows us to prescind solar tracking owing to its particular geometry. Chong et al. [10] exemplified this system using a set of borosilicate tubes to collect the necessary heat to power a multiple-effect diffusion unit (MDU), a type of distiller. Similarly, Liu et al. [11] evaluated the use of a vacuum tube collector attached to a multiple-effect distiller (MED). The use of borosilicate vacuum tubes, exclusively for solar desalination, was earlier reported by Sing et al. [12] and Kumar et al. [13], who calculated on the basis of a hypothesis that a flat-type still with a vacuum tube collector attached to it could distil up to $3800 \mathrm{~cm}^{3} / \mathrm{m}^{2}$ of water per day.

The main objective of the present study is to improve the performance of a stepped still and augment the volume of desalinated water it dribbles by incorporating internal reflective walls into it and externally attaching a set of borosilicate vacuum tubes with heat pipes. This set of tubes affixed to the stepped still distinguishes it from the other distillers used thus far. Via experiments, we evaluate the performance of the modified distiller and compare it with the performances of stepped stills without vacuum tubes. The data was collected during the summers of 2014 and 2015 in the city of Lima, Peru.

\section{Overview of the distiller}

The cascade solar still with internal reflective walls and a set of borosilicate vacuum tubes was constructed in a light wooden box with an opening on top, covered by a transparent glass of $1.25 \mathrm{~m}$ in length, $0.8 \mathrm{~m}$ in width, and $4 \mathrm{~mm}$ in thickness, that is to say, $1 \mathrm{~m}^{2}$. The interior

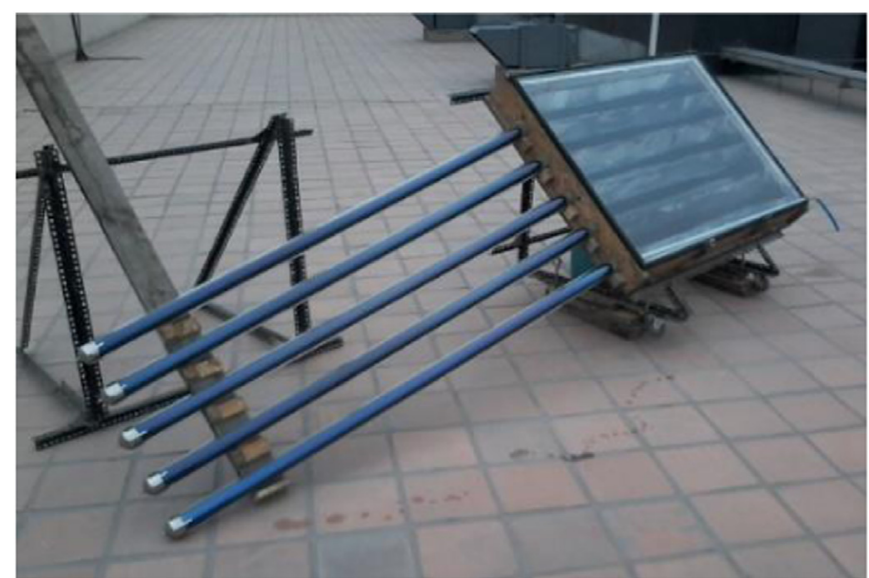

Fig. 2. Photograph of the stepped solar still comprising internal reflective walls and a set of attached borosilicate vacuum tubes.

of the box was lined with Styrofoam, which acted as a heat insulator. A bipod was used to keep the box tilted $45^{\circ}$ to the floor; this made it easier for condensed drops to diffuse through the glass, which would not have happened if it would have been tilted to only $12^{\circ}$ (Lima's latitude is $12^{\circ}$ south), as recommended by Singh and Tiwari [14]. The set comprised five tubes (the tube is $1.8 \mathrm{~m}$ long and $6 \mathrm{~cm}$ in diameter) running parallel to one another and containing their respective heat pipes; these pipes, in turn, passed through the lateral wall and still plate through an opening so that each heat pipe could come into direct contact with the seawater. Thus, the tubes would not fill up with seawater. Fig. 1 shows the design of the improved cascade solar still, and Fig. 2 shows a photograph of the still.

Inside the still, the lateral wall of the box and the glass cover fit perfectly into one another. Along its perimeter, each wall had a moldable sponge rubber profile adhered to it. This allowed the glass to lean on the box, and the weight of the glass was able to deform the rubber profiles and keep the box hermetically sealed (Fig. 3), without any vapor loss; moreover, no adhesives were required. In addition, the glass cover comprised a slightly inclined $U$-shaped aluminum chute attached to its internal inferior side; this allowed the still to collect desalinized water from the exterior part through one of the ends of the still (Fig. 1).

Each of the five plates of the distiller was $11.5-\mathrm{cm}$ wide and $116-\mathrm{cm}$ long and contained seawater 2-cm deep; by itself, it was able to hold $2668 \mathrm{~cm}^{3}(\sim 2.7 \mathrm{~L})$ of water, and the total volume in the still was $13,340 \mathrm{~cm}^{3}(\sim 13.3 \mathrm{~L})$. In addition, the vertical wall adjacent to each plate was made of high-reflectance aluminum; it was removable and could route solar radiation to the seawater (Fig. 4). Each plate was made of rust-resistant galvanized brass, and its internal base was completely covered with small, dark stones. Moreover, the plates were placed over wooden supports; they were, therefore, removable.

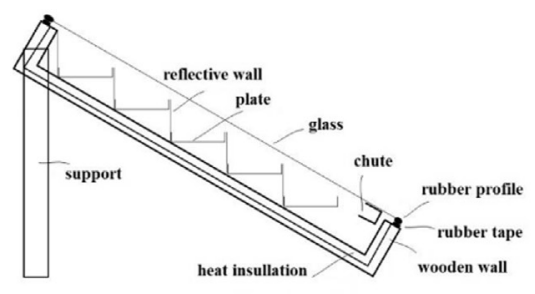

(a)

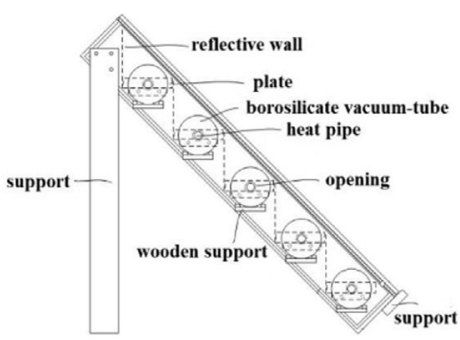

(b)

Fig. 1. Improved stepped solar still: (a) view of the transversal section and (b) lateral view. 


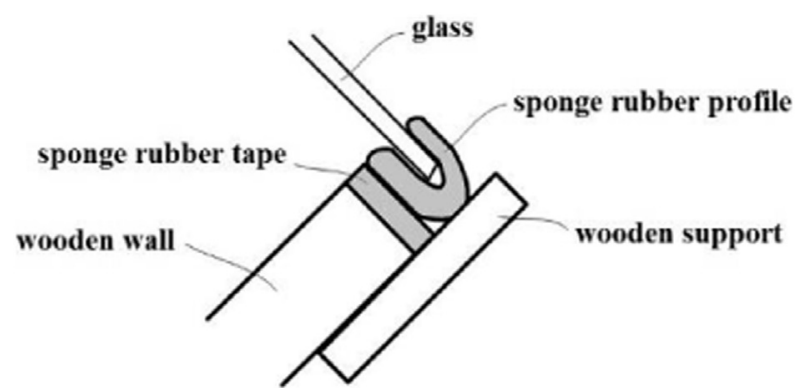

Fig. 3. Design of the sponge rubber profile and strip that deformed one another owing to the weight of the glass.

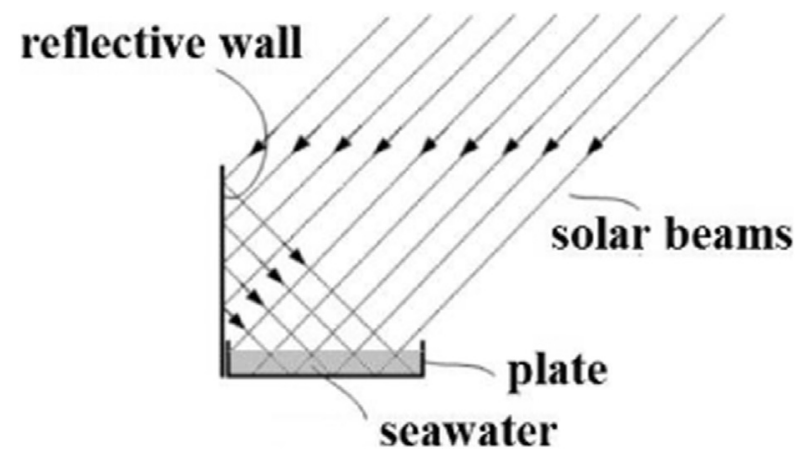

Fig. 4. Schematic of the trajectory of solar beams over the seawater.

\section{Experimental report}

The experiments were conducted at the University of Lima (207 $\mathrm{m}$ above the mean sea level, latitude $12.08^{\circ}$ South, longitude

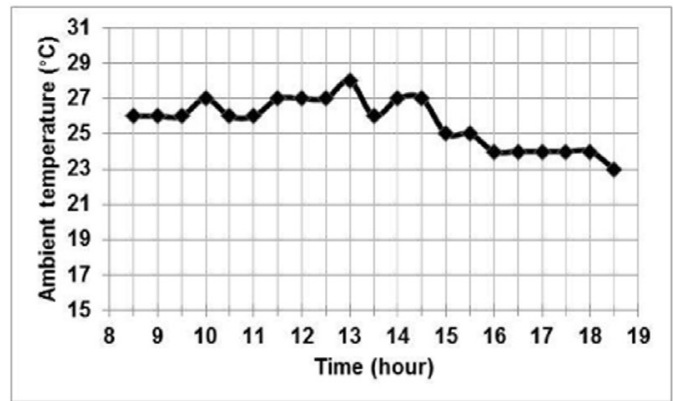

(a)

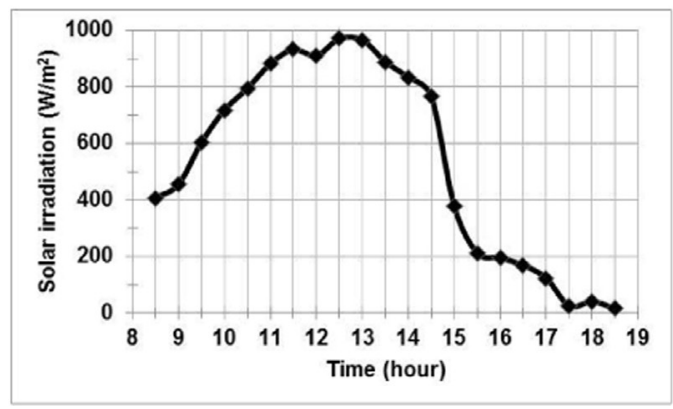

(c) $76.97^{\circ}$ West) during the summer of 2015 (from January to March). This paper shows the results obtained during four days in February, which was the hottest month that year in Lima. The ambient temperature was measured in the shade using a mercury thermometer (BOECO, graduated from -20 to $250^{\circ} \mathrm{C}$ ), whereas the temperature inside the still was measured using a Premium PR301 multitester (Praesk) equipped with a thermocouple. The irradiance was always measured perpendicularly to the floor using a TM-206 portable radiometer (Tenmars), and the volume of desalinated water was measured using a vessel graduated in milliliters. The values were taken every 30 min throughout the day; at 07:00 each day, 13.3 L of seawater were added to the plates of the still, and the still warm brine was collected at 21:00. This procedure ensured that the abrasion caused by the saltwater on the plates was low, which, in turn, helped increase their lifetime.

February 16, 2015 was a sunny day (with very little cloudiness and little wind) with an incidence of $19.93 \mathrm{MJ} / \mathrm{m}^{2}$ of solar energy over the course of the day, during which $4040 \mathrm{~cm}^{3}$ of desalinated water was obtained. Fig. 5 shows the obtained experimental data.

The production of desalinated water showed a local minimum at 13:00; this corresponds to the minimum solar irradiance observed at around 12:00 (Fig. 5(c)). A more detailed analysis of the data shows that between $11: 15$ and 12:40, there was moderate cloudiness, with an instantaneous minimum irradiance of $820 \mathrm{~W} / \mathrm{m}^{2}$. This possibly explains the slight reduction observed in the production form the still a few minutes later.

February 17 was a partially cloudy day in Lima until noon; the incident energy was $15.63 \mathrm{MJ} / \mathrm{m}^{2}$ and $3210 \mathrm{~cm}^{3}$ of desalinated water was obtained. It should be noted that during the night (between 18:00 and 20:00), an additional $50 \mathrm{~cm}^{3}$ was collected. Fig. 6 shows the experimental data obtained.

On February 20, 2015, the highest irradiation of $1115 \mathrm{~W} / \mathrm{m}^{2}$ was recorded at 12:30; this was despite the day being partially cloudy during the morning, clear from noon until 14:30, and again partially cloudy until the end. An energy of $20.07 \mathrm{MJ} / \mathrm{m}^{2}$ was calculated for

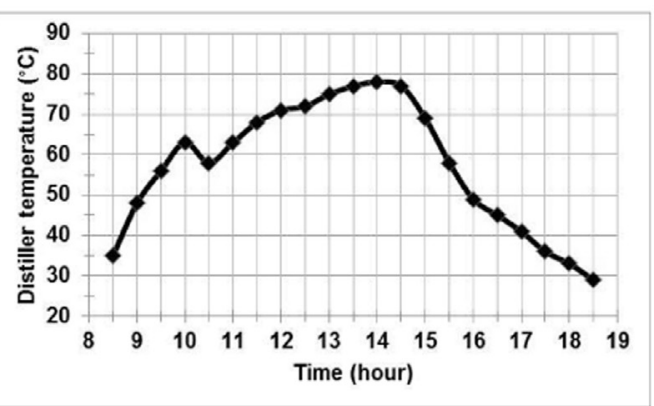

(b)

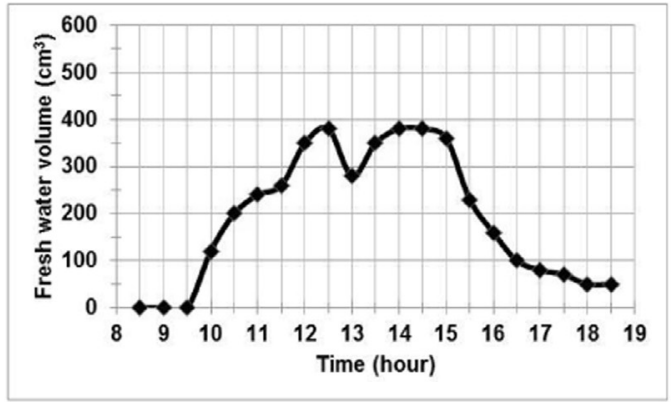

(d)

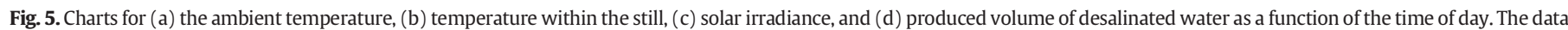
was obtained on February 16, 2015 at the University of Lima. 


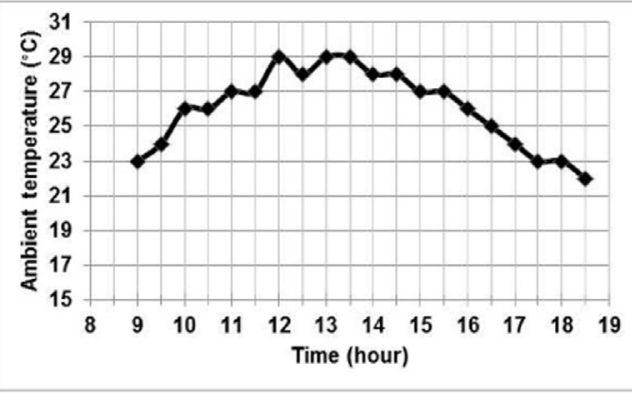

(a)

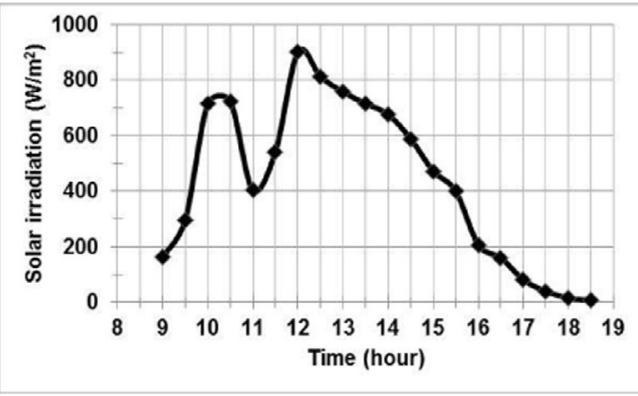

(c)

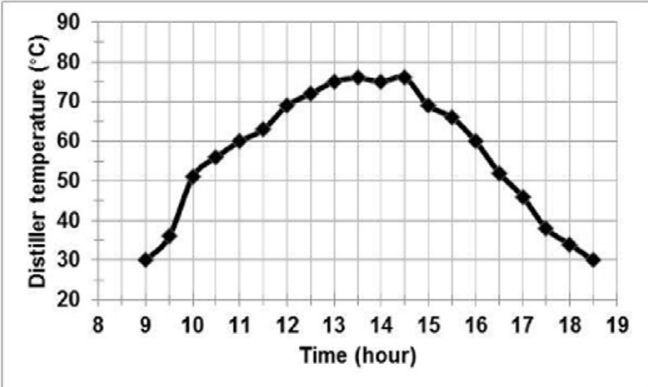

(b)

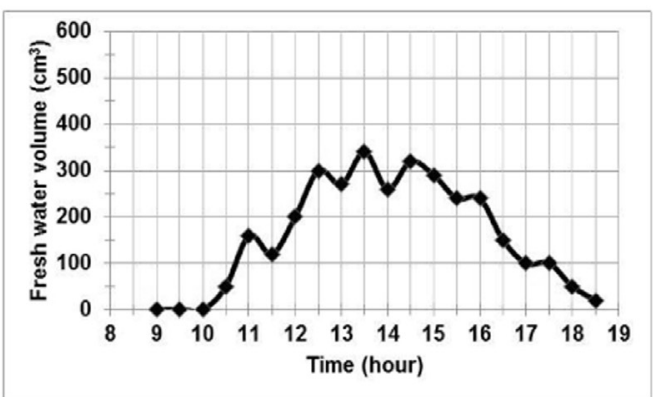

(d)

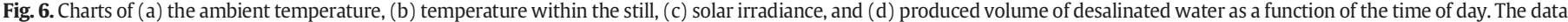
was obtained on February 17, 2015 at the University of Lima.

the day, and $3920 \mathrm{~cm}^{3}$ of desalinated water was obtained along with an additional $70 \mathrm{~cm}^{3}$ until 20:00. Fig. 7 shows the experimental data.

February 21 was partly cloudy but with intense sunshine at around 13:00; the incident energy was $12.63 \mathrm{MJ} / \mathrm{m}^{2}$, and only $2590 \mathrm{~cm}^{3}$ of desalinated water was obtained. Fig. 8 shows the experimental data.

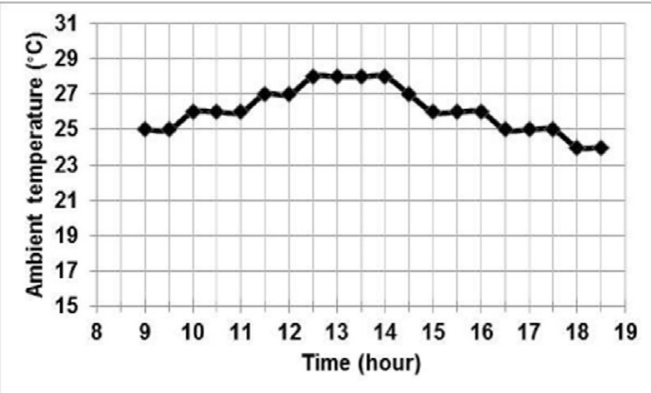

(a)

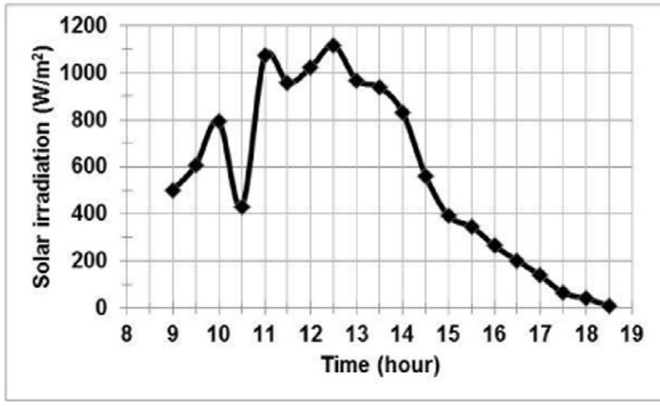

(c)

\section{Analysis of the results}

\subsection{Distilled water volume as a function of solar energy}

Each day, the incident solar energy was calculated out of the area of the chart for the irradiance as a function of time. Table 1 shows the

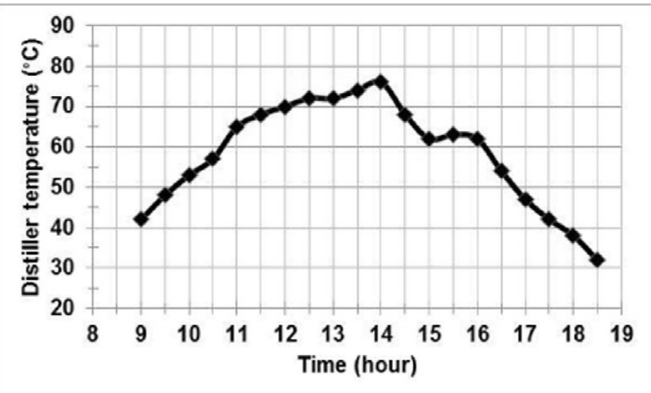

(b)

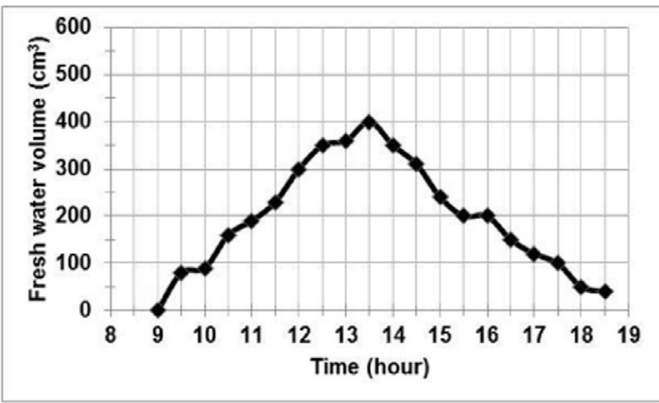

(d)

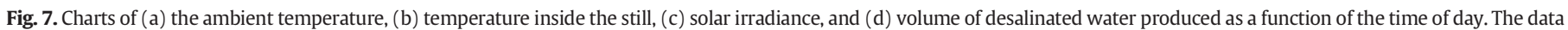
was obtained on February 20, 2015 at the University of Lima. 


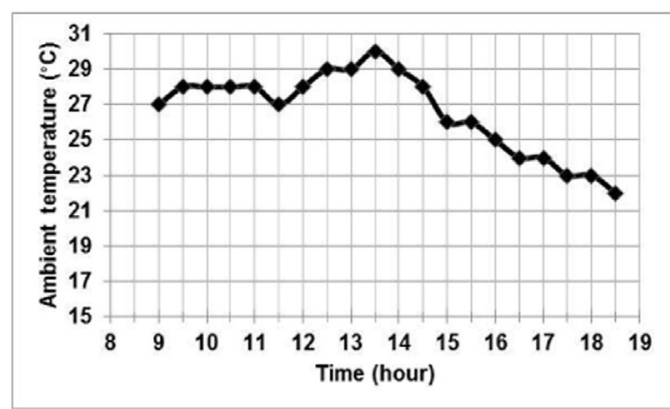

(a)

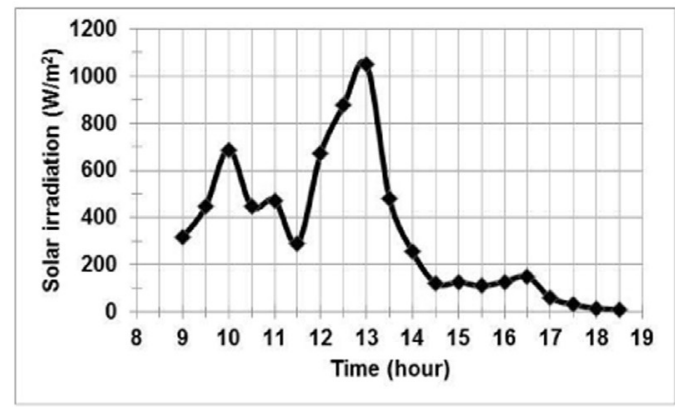

(c)

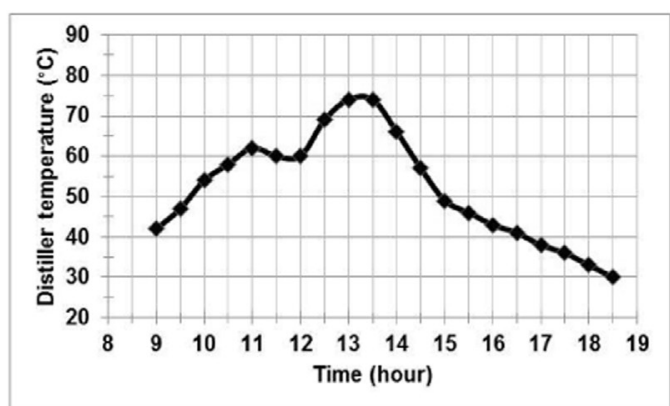

(b)

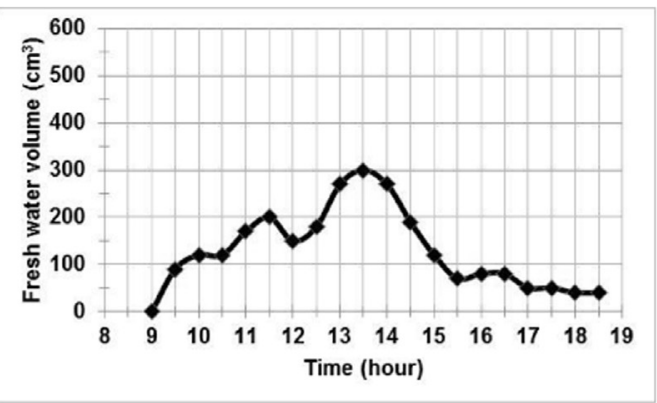

(d)

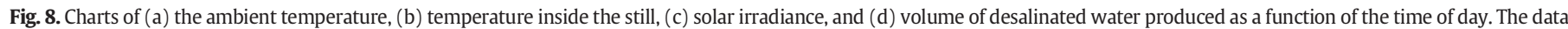
was obtained on February 21, 2015 at the University of Lima.

Table 1

Daily solar energy values and volume of distilled water produced.

\begin{tabular}{lll}
\hline Date & $E\left(\mathrm{MJ} / \mathrm{m}^{2} /\right.$ day $)$ & $V_{\text {exp }}\left(\mathrm{cm}^{3} /\right.$ day $)$ \\
\hline $02 / 16 / 15$ & 19.93 & 4040 \\
$02 / 17 / 15$ & 15.63 & 3210 \\
$02 / 20 / 15$ & 20.07 & 3990 \\
$02 / 21 / 15$ & 12.63 & 2590 \\
\hline
\end{tabular}

values of the daily solar energy $(E)$ and the volume of desalinated water produced $\left(V_{\text {exp }}\right)$.

Fig. 9 shows the volume of desalinated water as a function of the total daily solar energy; it uses the data given in Table 1.

From this graph, we can see that the amount of desalinated water obtained increased with the amount of incident energy, as expected. Visually, it is an almost linear dependence, at least in the interval between

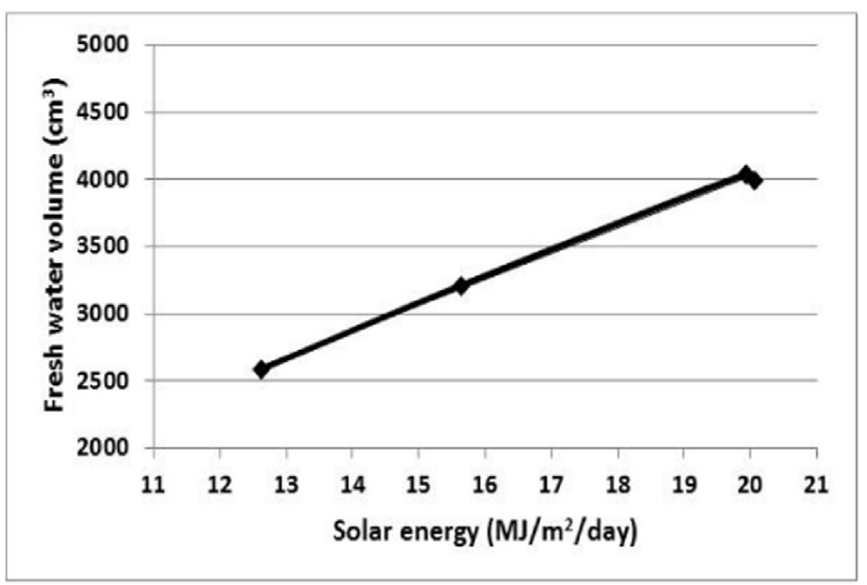

Fig. 9. Volume of desalinated water produced as a function of the total solar energy.
12 and $20 \mathrm{MJ} / \mathrm{m}^{2}$ per day; however, it is known that the production of water depends on several additional factors. The linear equation that governs the dependence between distilled water volume (in $\mathrm{cm}^{3}$ ) and incident solar energy (in MJ per day) is given as

$V\left[\mathrm{~cm}^{3}\right]=191.74 E\left[\frac{\mathrm{MJ}}{\text { day }}\right]+185.24$

with an $\mathrm{R}^{2}$ of 0.991 . Due to the unfortunate fact that complete data was available for a limited period of four days, the results can only be preliminary; it is, therefore, necessary to collect more information to corroborate them.

Table 2

Values of the total solar energy $(E)$ and the maximum temperature reached in the still $\left(T_{i}^{\max }\right)$.

\begin{tabular}{lll}
\hline Date & $E\left(\mathrm{MJ} / \mathrm{m}^{2} /\right.$ day $)$ & $T_{i}^{\max }\left({ }^{\circ} \mathrm{C}\right)$ \\
\hline $02 / 16 / 15$ & 19.93 & 78 \\
$02 / 17 / 15$ & 15.63 & 76 \\
$02 / 20 / 15$ & 20.07 & 76 \\
$02 / 21 / 15$ & 12.63 & 74 \\
\hline
\end{tabular}

Table 3

Values of the total incident energy, theoretical volume of desalinated water, and improved still efficiency.

\begin{tabular}{lllll}
\hline Date & $E_{\text {total }}(\mathrm{MJ} /$ day $)$ & $V_{\text {exp }}\left(\mathrm{cm}^{3} /\right.$ day $)$ & $V_{\text {theo }}\left(\mathrm{cm}^{3} /\right.$ day $)$ & $\eta(\%)$ \\
\hline $02 / 16 / 15$ & 14.15 & 4040 & 5660 & 71.4 \\
$02 / 17 / 15$ & 11.10 & 3210 & 4439 & 72.3 \\
$02 / 20 / 15$ & 14.25 & 3990 & 5700 & 70.0 \\
$02 / 21 / 15$ & 8.97 & 2590 & 3587 & 72.2 \\
\hline
\end{tabular}


Table 4

Total solar energy $\left(E_{\text {total }}\right)$, volume of water produced $\left(V_{\text {exp }}\right)$, volume produced per unit area $\left(V^{\prime}{ }_{\exp }\right)$, and the volume per unit area and per unit incident solar energy $\left(V^{\prime \prime}{ }_{\exp }\right)$.

\begin{tabular}{lllll}
\hline Date & $\begin{array}{l}E_{\text {total }} \\
(\mathrm{MJ} / \text { day })\end{array}$ & $\begin{array}{l}V_{\text {exp }} \\
\left(\mathrm{cm}^{3} / \text { day }\right)\end{array}$ & $\begin{array}{l}V^{\prime}{ }_{\exp } \\
\left(\mathrm{cm}^{3} / \mathrm{m}^{2} / \text { day }\right)\end{array}$ & $\begin{array}{l}V_{\exp }^{\prime \prime} \\
\left(\mathrm{cm}^{3} / \mathrm{m}^{2} / \mathrm{MJ} / \text { day }\right)\end{array}$ \\
\hline $02 / 16 / 15$ & 14.15 & 4040 & 5690 & 285.5 \\
$02 / 17 / 15$ & 11.10 & 3210 & 4521 & 289.3 \\
$02 / 20 / 15$ & 14.25 & 3990 & 5620 & 280.0 \\
$02 / 21 / 15$ & 8.97 & 2590 & 3648 & 288.8 \\
\hline
\end{tabular}

\subsection{Global efficiency}

The global efficiency $(\eta)$ of the stepped still can be defined as the ratio between the amount of experimentally produced water $\left(V_{\text {exp }}\right)$ and the amount of water that would theoretically be produced if the total solar energy incident on the still was exclusively used for the evaporation of the seawater $\left(V_{\text {theo }}\right)$. This expression is depicted in the following equation:

$\eta=\frac{V_{\text {exp }}}{V_{\text {theo }}} \times 100 \%$

The temperature of the seawater in the still is considered to vary from the ambient temperature (as the seawater was collected a few days prior to the experiment) to approximately $76{ }^{\circ} \mathrm{C}$, which is the average of the maximum temperatures reached in the still during the four days of February in which the data was collected. Table 2 shows the daily values.

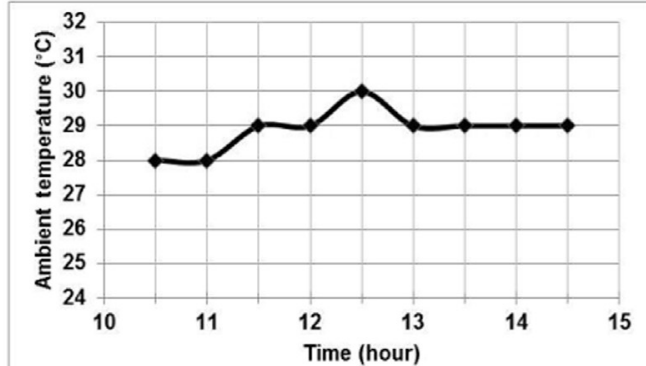

(a)

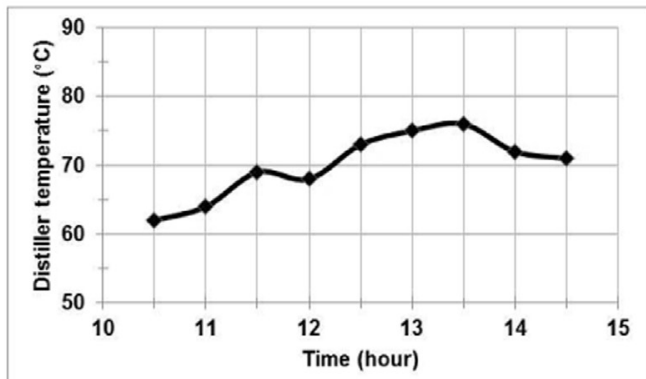

(b)
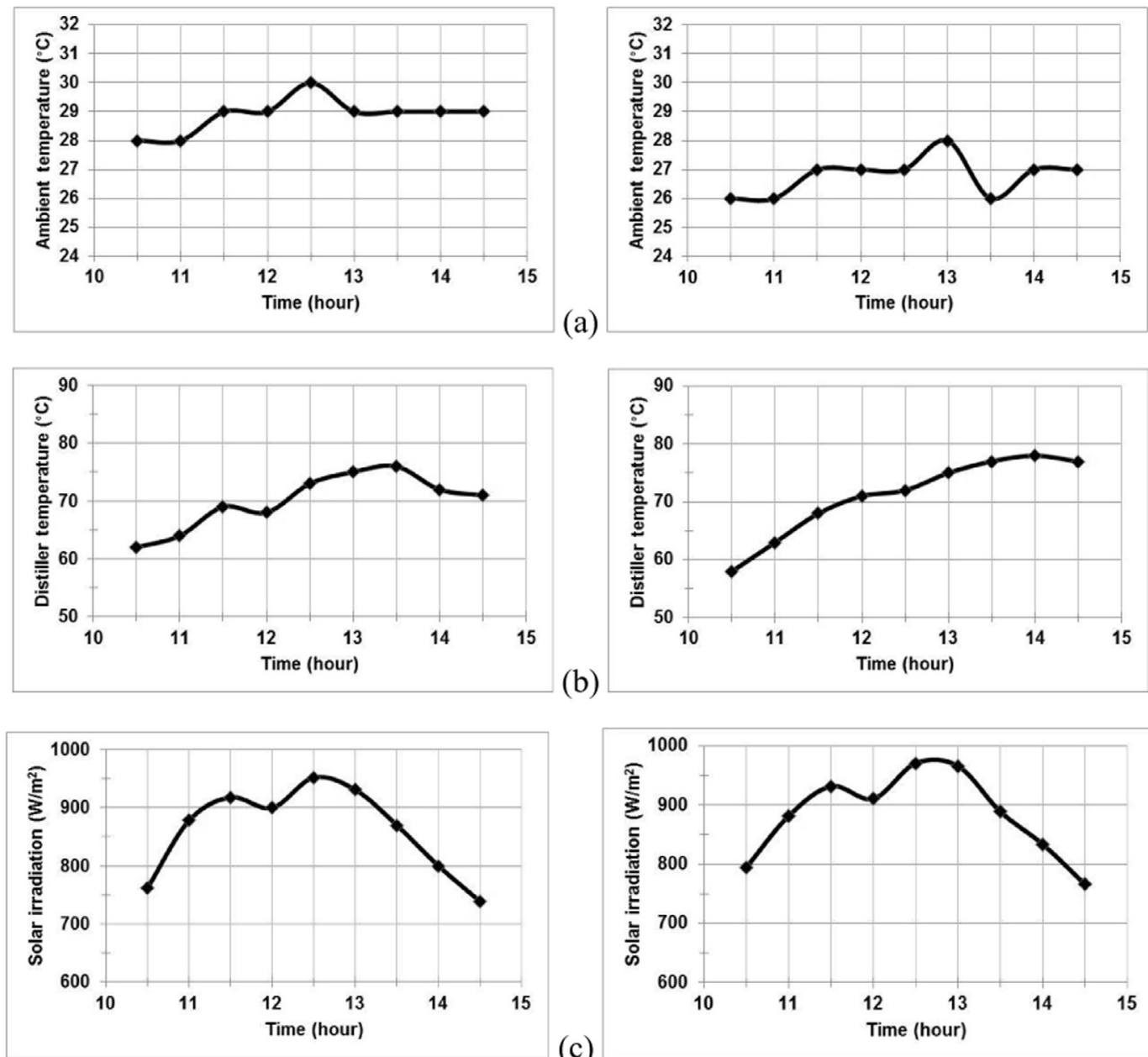

(c)
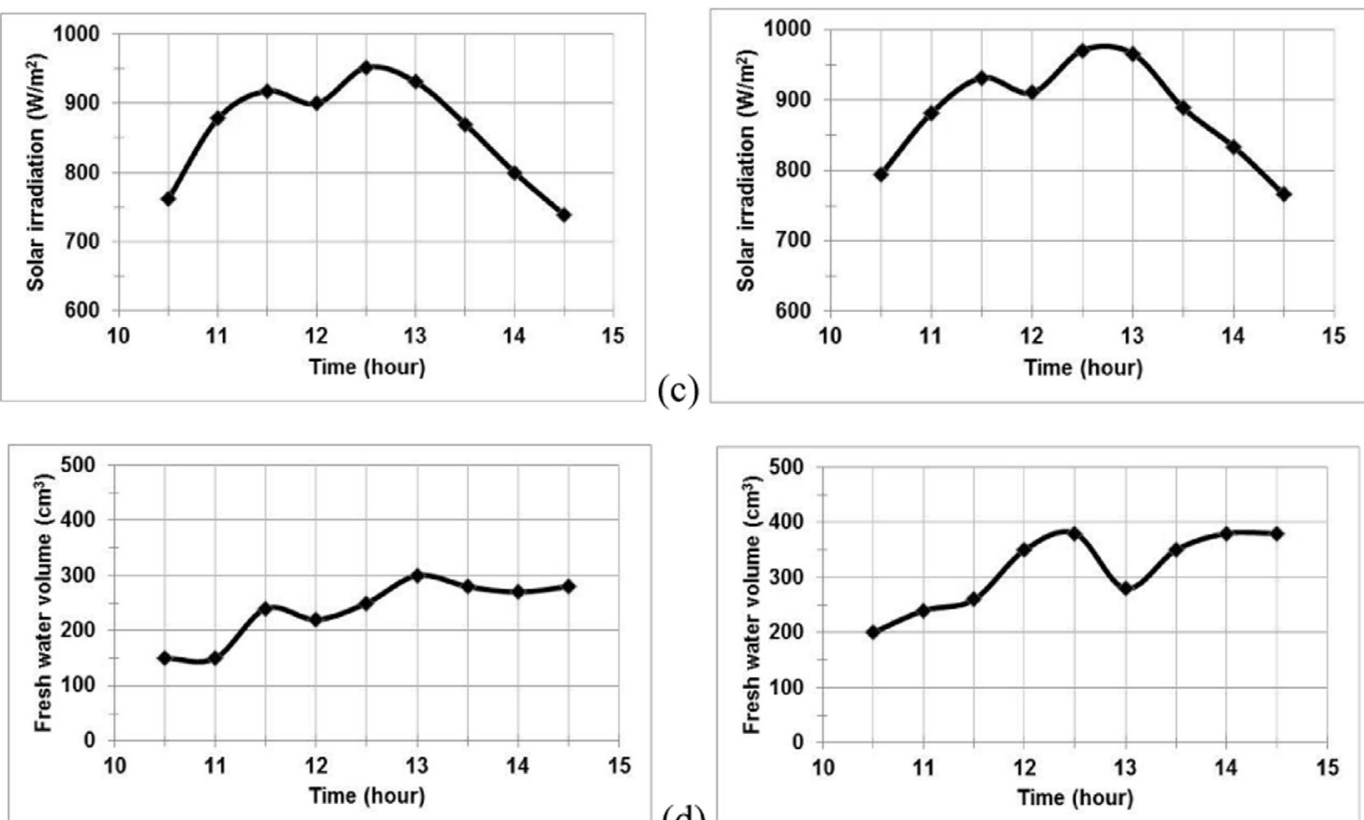

(d)

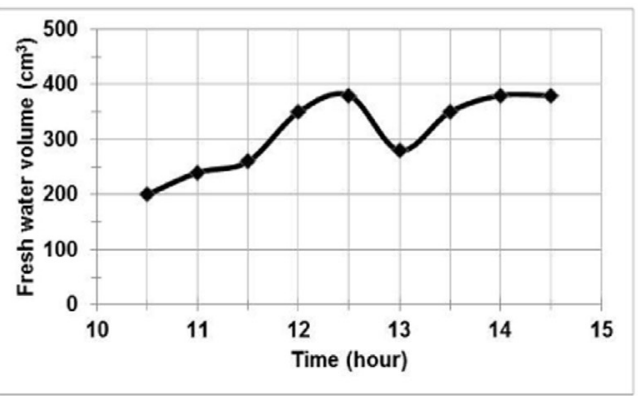

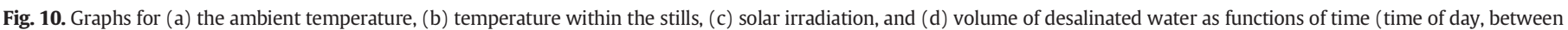
10:30 and 14:30) on February 16, 2015 (with borosilicate tubes, left column) and February 22, 2014 (without borosilicate tubes, right column). 
The specific heat of seawater with $3.5 \%$ salinity is $\sim 4000 \mathrm{~J} / \mathrm{kg}{ }^{\circ} \mathrm{C}$ at $30{ }^{\circ} \mathrm{C}$ and $4050 \mathrm{~J} / \mathrm{kg}^{\circ} \mathrm{C}$ at $0{ }^{\circ} \mathrm{C}$ [15]. Notably, this value increases very slightly with reduction in temperature (only $1.25 \%$ from $0{ }^{\circ} \mathrm{C}$ to $30{ }^{\circ} \mathrm{C}$ ); therefore, for simplification, we considered this value to be constant in our calculations. The temperature of the seawater increased from $26^{\circ} \mathrm{C}$ (average temperature at the beginning of the day) to $76^{\circ} \mathrm{C}$, i.e., $\Delta T=50{ }^{\circ} \mathrm{C}$. Thus, theoretically, the amount of sensible heat is $0.2 \mathrm{MJ} / \mathrm{kg}$. If we consider that the latent heat of water evaporation at $80{ }^{\circ} \mathrm{C}$ is $2308 \mathrm{MJ} / \mathrm{kg}[16,17]$, then the total amount of energy needed to evaporate $1 \mathrm{~kg}$ of sea water (between $75{ }^{\circ} \mathrm{C}$ and $80{ }^{\circ} \mathrm{C}$ ) is $\sim 2.5 \mathrm{MJ} / \mathrm{kg}$.

Moreover, if the effective area of the still $(A)$ is $0.71 \mathrm{~m}^{2}$, the incident solar energy on the still during the day can be calculated using the following expression:

$E_{\text {total }}=E \times A$

Thus, the theoretical volume of distilled water $\left(V_{\text {theo }}\right)$ can be considered as the ratio between the total energy captured by the still and the energy required to increase the temperature of the seawater by $50{ }^{\circ} \mathrm{C}$ and thereby completely evaporate it. It is calculated as follows:

$V_{\text {theo }}\left[\mathrm{cm}^{3}\right]=\frac{E_{\text {total }}[\mathrm{MJ}]}{2.5} \times 10^{3} \pi$

The global efficiency of the still can be obtained using Eqs. (2), (3), and (4). Table 3 shows the results of these calculations.

It is important to note that the global efficiency of the still varied slightly despite its operating under different climatic conditions; the average value obtained was $71.5 \%$. A number of authors have reported that they increased the global efficiency of their systems by applying various modifications aimed at increasing the temperature difference between the evaporation and condensation surfaces [18]. For example, in one study hot air was injected into a still whereas the glass cover was cooled in another; this increased the global efficiency of these stills by $52 \%$ and $59 \%$, respectively [18].

\subsection{Distilled water production}

Table 4 shows the amount of desalinated water produced per unit area of the still $\left(V_{\text {exp }}^{\prime}\right)$. Over the four days, the amount produced varied from 3648 to $5690 \mathrm{~cm}^{3} / \mathrm{m}^{2}$ per day; this depended on if it had been cloudy or sunny on a given day. Similarly, $V^{\prime \prime}$ exp is defined as the amount of desalinated water produced in a day per unit area and per unit incident solar energy. As shown in Table 4, mostly consistent values were obtained for this parameter, and the average $V^{\prime \prime}{ }_{\exp }$ was $285.9 \mathrm{~cm}^{3} / \mathrm{m}^{2} \mathrm{MJ}$ per day. This parameter better characterizes the performance of the solar still than $V^{\prime}$ exp ; thus, a greater $V^{\prime \prime} \exp _{\text {corresponds }}$ to a still that has performed better.

From this table, we can see that while the $V^{\prime} \exp$ varies by $43.7 \%$ between its maximum and minimum values, $V^{\prime \prime}$ exp varies only by $3.1 \%$. This could be explained by assuming that size and solar energy are the main factors affecting the performance of the distiller, while other

Table 5

Values for the average ambient temperatures, average temperatures inside the stills, solar energies, and volumes of distilled water between 10:30 and 14:30 on two given days for stills that did and did not contain vacuum tubes.

\begin{tabular}{llllll}
\hline Date & $\begin{array}{l}\bar{T}_{a m b} \\
\left({ }^{\circ} \mathrm{C}\right)\end{array}$ & $\begin{array}{l}\bar{T}_{\text {int }} \\
\left({ }^{\circ} \mathrm{C}\right)\end{array}$ & $\begin{array}{l}E \\
\left(\mathrm{MJ} / \mathrm{m}^{2} / \text { day }\right)\end{array}$ & $\begin{array}{l}V_{\text {exp }} \\
\left(\mathrm{cm}^{3}\right)\end{array}$ & $\begin{array}{l}\text { Stepped still with } \\
\text { internal reflector }\end{array}$ \\
\hline $02 / 16 / 2015$ & 26.8 & 71 & 14.26 & 2820 & With vacuum tubes \\
$02 / 22 / 2014$ & 28.9 & 70 & 14.34 & 2140 & Without vacuum tubes \\
\hline
\end{tabular}

Table 6

Global efficiencies, $V^{\prime}$ exp , and $V^{\prime \prime}$ exp calculated between 10:30 and 14:30 on two given days for stills that did and did not comprise a set of borosilicate vacuum tubes.

\begin{tabular}{lllll}
\hline Date & $\eta(\%)$ & $V_{\text {exp }}^{\prime}\left(\mathrm{cm}^{3} / \mathrm{m}^{2}\right)$ & $V_{\text {exp }}^{\prime \prime}\left(\mathrm{cm}^{3} / \mathrm{m}^{2} / \mathrm{MJ}\right)$ & $\begin{array}{l}\text { Cascade still with } \\
\text { internal reflector }\end{array}$ \\
\hline $02 / 16 / 2015$ & 69.6 & 3971.8 & 278.5 & With vacuum tubes \\
$02 / 22 / 2014$ & 52.5 & 3014.1 & 210.2 & Without vacuum tubes \\
\hline
\end{tabular}

factors such as wind speed or ambient temperature, for example, are not as important.

\subsection{Comparison with a stepped still without borosilicate vacuum tubes}

In the summer of 2014, experiments were performed at the University of Lima using the same type of stepped still but without borosilicate vacuum tubes [19]. We compared the experimental data obtained on February 22, 2014 (for a cascade still without vacuum tubes) and February 16, 2015 (for a stepped still with vacuum tubes) due to weather conditions were very similar. In addition, we chose to only compare the interval between 10:30 and 14:30 because in this period, the solar irradiance and the temperature inside the still were very similar, too. However, as shown in Fig. 10, the $V_{\text {exp }}$ was significantly different.

The average ambient temperatures $\left(\bar{T}_{a m b}\right)$, average temperatures inside the stills $\left(\bar{T}_{\text {int }}\right)$, and incident solar energies $(E)$ are shown in Table 5. Although these three variables were very similar, the $V_{\text {exp }}$ was quite different.

The results show that when the vacuum tubes were used, $31.8 \%$ more distilled water was produced even though the ambient temperature was $2{ }^{\circ} \mathrm{C}$ lower and the solar energy was slightly lower $(0.6 \%)$ than when tubes did not were used. The global efficiency values as well as $V_{\text {exp }}^{\prime}$ and $V^{\prime \prime} \exp$ obtained for the two stills are shown in Table 6.

\section{Conclusions}

The features of solar distiller comprising internal reflective walls enhanced with a set of borosilicate vacuum tubes are described in this paper. The heat collected by these tubes was transferred to seawater through the heat pipes contained in each tube. We determined that the average global efficiency of this distiller was $71.5 \%$.

Experimentally, we obtained $4040 \mathrm{~cm}^{3}$ of desalinated water on a sunny day in Lima $\left(19.9 \mathrm{MJ} / \mathrm{m}^{2}\right.$ per day) and $2590 \mathrm{~cm}^{3}$ on a cloudy day $\left(12.6 \mathrm{MJ} / \mathrm{m}^{2}\right.$ per day). This result corresponds to a $V^{\prime}{ }_{\text {exp }}$ of 5690 and $3648 \mathrm{~cm}^{3} / \mathrm{m}^{2}$ per day for a sunny and cloudy day, respectively. However, $V^{\prime \prime}{ }_{\text {exp }}$ values were 285.5 and $288.8 \mathrm{~cm}^{3} / \mathrm{m}^{2}$ MJ per day for a sunny and a cloudy day, respectively. This parameter did not vary significantly under different weather conditions.

Finally, we experimentally verified that the production of desalinated water increases by $31.8 \%$ when a set of borosilicate vacuum tubes with heat pipes is attached to stepped solar distiller comprising internal reflectors. Moreover, the global efficiency and $V^{\prime \prime}{ }_{\exp }$ of such a distiller are $32.5 \%$ greater than those for the same distiller without a set of vacuum tubes $\left(\eta=69.2 \%\right.$ against $52.5 \%$, and $V^{\prime \prime}{ }_{\exp }=278.5$ against $210.2 \mathrm{~cm}^{3} / \mathrm{m}^{2} \mathrm{MJ}$ per day). This last parameter is good to use when evaluating the performance of a distiller because it minimizes the effect that variations in weather conditions may have.

\section{Acknowledgements}

The authors are grateful to the technicians at the Faculty of Industrial Engineering laboratories of the University of Lima. Additionally, we thank the logistical and financial support provided by the Institute for Scientific Research (PI.56.014.2013 and PI.56.015.2014) (IDIC, in Spanish), University of Lima. 


\section{References}

[1] Ministry of Health of Peru, National Plan to Reduce Chronic Child malnutrition and anemia prevention in the country, period 2014-2016: white paper, published by the National Institute of Health - Lima: Ministry of Health, National Institute of Health 2014 15-16 Web link accessed on 19.07.2016 http://www.minsa.gob.pe/portada/ Especiales/2015/Nutriwawa/directivas/005_Plan_Reduccion.pdf.

[2] M.S.S. Abujazar, S. Fatihah, A.R. Rakmi, M.Z. Shahrom, The effects of design parameters on productivity performance of a solar still for seawater desalination - a review, Desalination 385 (2016) 178-193 http://dx.doi.org/10.1016/j.desal.2016.02.025.

[3] A.E. Kabeel, A.M. Hamed, S.A. El-Agouz, Cost analysis of different solar still configurations, Energy 35 (2010) 2901-2908 http://dx.doi.org/10.1016/j.energy.2010.03.021.

[4] S.M.A. Moustafa, G.H. Brusewitz, D.M. Farmer, Direct use of solar energy for wate desalination, Sol. Energy 22 (1979) 141-148 http://dx.doi.org/10.1016/0038092X(79)90098-7.

[5] I.M. Muslih, S.M. Abdallah, W.A. Husain, Cost comparative study for new water distillation techniques by solar energy using, Appl. Solar Energy 46 (1) (2010) 8-12 http://dx.doi.org/10.3103/S0003701X10010032.

[6] A.S. Abdullah, Improving the performance of stepped solar still, Desalination 319 (2013) 60-65 http://dx.doi.org/10.1016/j.desal.2013.04.003.

[7] V. Velmurugan, K.J. Kumar, T.N. Haq, K. Srithar, Performance analysis in stepped solar still for effluent desalination, Energy 34 (2009) 1179-1186 http://dx.doi.org/ 10.1016/j.energy.2009.04.029

[8] Z.M. Omara, A.E. Kabeel, M.M. Younes, Enhancing the stepped solar still performance using internal reflectors, Desalination 314 (2013) 67-72 http://dx.doi.org/ 10.1016/j.desal.2013.01.007.

[9] Z.M. Omara, A.E. Kabeel, M.M. Younes, Enhancing the stepped solar still performance using internal and external reflectors, Energy Convers. Manag. 78 (2014) 876-881 http://dx.doi.org/10.1016/j.enconman.2013.07.092.
[10] T.-L. Chong, B.-J. Huang, P.H. Wu, Y.-C. Kao, Multiple-effect diffusion solar still coupled with a vacuum-tube collector and heat pipe, Desalination 347 (2014) 66-76 http://dx.doi.org/10.1016/j.desal.2014.05.023.

[11] X. Liu, W. Chen, M. Gu, S. Shen, G. Cao, Thermal and economic analyses of solar desalination system with evacuated tube collectors, Sol. Energy 93 (2013) 144-150 http://dx.doi.org/10.1016/j.solener.2013.03.009.

[12] R.V. Singh, S. Kumar, M.M. Hasan, M.E. Khan, G.N. Tiwari, Performance of a solar still integrated with evacuated tube collector in natural mode, Desalination 318 (2013) 25-33 http://dx.doi.org/10.1016/j.desal.2013.03.012.

[13] S. Kumar, A. Dubey, G.N. Tiwari, A solar still augmented with an evacuated tube collector in forced mode, Desalination 347 (2014) 15-24 http://dx.doi.org/10.1016/j. desal.2014.05.019.

[14] H.N. Singh, G.N. Tiwari, Monthly performance of passive and active solar stills for different Indian climatic conditions, Desalination 168 (2004) 145-150 http://dx. doi.org/10.1016/j.desal.2004.06.180.

[15] O.I. Mamayev, Temperature - Salinity Analysis of World Ocean Waters, Elsevier, The Netherlands, 2010.

[16] K.N. Marsh, Recommended Reference Materials for the Realization of Physicochemical Properties, Blackwell, Oxford, 1987.

[17] P.M.E. Koffi, H.Y. Andoh, P. Gbaha, S. Touré, Theoretical and experimental study of solar water heater with internal exchanger using thermosiphon system, Energy Convers. Manag. 49 (2008) 2279-2290 http://dx.doi.org/10.1016/enconman.2008. 01.032.

[18] P.K. Abdenacer, S. Nafila, Impact of temperature difference (water-solar collector) on solar-still global efficiency, Desalination 209 (2007) 298-305 http://dx.doi.org/ 10.1016/j.desal.2007.04.043.

[19] E. Saettone, Y. Valencia, Comparison between solar distillers with and without solar concentrator, Appl. Solar Energy 52 (2) (2016) 131-136 http://dx.doi.org/10.3103/ S0003701X16020201. 